Article

\title{
Influence of Slag Cement on the Permeability of Concrete for Biological Shielding Structures
}

\author{
Daria Jóźwiak-Niedźwiedzka *®e, Mariusz Dąbrowski® ${ }^{\circledR}$, Karolina Bogusz and \\ Michał A. Glinicki 10 \\ Institute of Fundamental Technological Research Polish Academy of Sciences, Pawińskiego 5b, 02-106 Warsaw, \\ Poland; mdabrow@ippt.pan.pl (M.D.); kgibas@ippt.pan.pl (K.B.); mglinic@ippt.pan.pl (M.A.G.) \\ * Correspondence: djozwiak@ippt.pan.pl; Tel.: +48-22-8261281 (ext. 310)
}

Received: 30 July 2020; Accepted: 1 September 2020; Published: 3 September 2020

check for updates

\begin{abstract}
Durability of concrete designed for radiation shielding structures is an important issue in nuclear power plant safety. An investigation of the permeability of concrete containing heavyweight aggregates and water-bearing aggregates was performed with respect to gaseous and liquid media. Mix design was developed using Portland and slag cement, crushed magnetite and serpentine aggregate. The use of slag cement in concrete containing magnetite and serpentine aggregates resulted in the substantial improvement of the compressive strength in comparison with Portland cement concrete. The application of slag cement was found to reduce the chloride ingress, regardless of the special aggregate use. The coefficient of chloride migration was within the range $5 \div 8 \times 10^{-12} \mathrm{~m}^{2} / \mathrm{s}$ and $17 \div 25 \times 10^{-12} \mathrm{~m}^{2} / \mathrm{s}$ for slag cement concrete and Portland cement concrete, respectively. At the same time, the carbonation depth was increased twice for slag cement concrete in comparison to Portland cement concrete. However, the maximum carbonation depth after one year of exposure to $1 \% \mathrm{CO}_{2}$ was only $14 \mathrm{~mm}$ for slag cement concrete, and $7 \mathrm{~mm}$ for reference concrete. The total pore volume evaluated using mercury intrusion porosimetry was influenced by the type of special aggregate used. It was shown that concrete with various contents of magnetite aggregate and slag cement achieved the smallest total pore volume. While serpentine coarse aggregate caused an increase in total pore volume in comparison to concrete with magnetite aggregate.
\end{abstract}

Keywords: chloride permeability; carbonation; slag cement; radiation shielding concrete; microstructure; MIP; mix design; Portland cement; magnetite

\section{Introduction}

Nuclear power is a sustainable and carbon-free source of electricity. Increased interest to build new nuclear power plants has been observed due to growing environmental concerns related to fossil fuel energy sources. Additionally, the total cost of using nuclear energy in energy and electricity plans and policies is significantly lower than that of other energy sources, including renewable energy sources [1]. However, after the accident of the Fukushima Daiichi nuclear power plant in 2011, the public opinion trends demonstrated a lower degree of trust in nuclear energy technologies and facilities. In response, significant enhancements of key plant safety functions, in particular related to large-scale natural disasters, were introduced [2]. Nuclear safety-related concrete structures are constantly required to provide both structural and radiation shielding functions. For economic reasons the expected service life of principal concrete structures should be at least 60 years. Therefore, the problem of adequate long-term durability of concrete exposed to harsh environmental conditions becomes significant [3-5].

In [6], the environmental conditions were reviewed both for nuclear containment structures and biological shielding structures. The durability design is largely based on a suitable selection of concrete constituents and mix proportioning that is guided by the combined action of radiation, 
increased temperature and mechanical actions, also moisture transport and chemical factors. Improvement of concrete shielding properties for the attenuation of photons and neutrons is obtained by using selected heavyweight mineral aggregates and/or aggregates containing lightweight elements [7] or boron minerals [8]. High-performance heavy density concrete mixes for gamma-ray shielding were developed by Ouda [9] using different aggregates and mineral additions. The compressive strength exceeding $60 \mathrm{MPa}$ was considered as the principal indicator of high performance; the target strength was achieved for concrete containing magnetite coarse aggregate and $10 \%$ of silica fume per cement mass. Concrete mixes made with goethite and serpentine coarse aggregate along with silica fume, fly ash and blast furnace slag addition did not satisfy such strength requirements even after 90 days of curing. The influence of heavyweight concrete mix design on the resistance to thermal shock exposure was revealed in [10] and allowed to verify the integrity of the shielding concrete over the different temperature ranges.

The investigations conducted by Sakr and El-Hakim, Sakr, K., et al. [11] concerned the effect of high temperature $\left(250,500,750\right.$ and $\left.950^{\circ} \mathrm{C}\right)$ on the physical, mechanical and radiation properties of heavyweight concrete. They showed that concrete with ilmenite aggregate was characterized by the highest density and lowest absorption percent, and it also had higher values of mechanical properties (compressive, tensile, bending and bonding strength) than gravel or barite concrete. Ilmenite concrete was more resistant to elevated temperature and it showed the highest attenuation of transmitted gamma rays as well. Yousef et al. [12] analyzed serpentine and hematite concretes exposed to temperatures between 20 and $800{ }^{\circ} \mathrm{C}$. They have found that concrete with hematite aggregate was characterized by the best resistance for high-temperature effects. It did not lose more than $30 \%$ of its compressive strength up to $500^{\circ} \mathrm{C}$, while reference concretes with gravel or dolomite aggregate failed completely at $500^{\circ} \mathrm{C}$. They revealed that serpentine and hematite aggregates were more thermally stable comparing to dolomite aggregate in shielding concrete.

The influence of the cement type, in this largely slag cement, on the durability of concrete has been the subject of many studies and scientific publications, Al-Amoudi, O.S.B., et al. [13-25]. The research concerning the permeability of slag cement concrete was conducted for both chloride ion migration [18,19] and carbonation [20-22]. Slag cement plays a positive role in improving the durability of concrete, where chloride ion may cause serious deterioration to the reinforced concrete structures, Feng, N.-Q., et al. [17]. The carbonation depths and consequently the carbonation coefficients increase with increasing slag content $[16,23,24]$. This dependency was expected, because of the slag pore solutions is low and since $\mathrm{CO}_{2}$ preferentially reacts with Portlandite, the $\mathrm{pH}$ is rapidly reduced, Gruyaert, E., et al. [23]. It is also known that the gas permeability of the concrete increases with increasing slag content [25] and the carbonation reaction in slag cement concrete leads to a coarsening of the pore structure allowing carbon dioxide to penetrate more easily in the concrete, Gruyaert, E., et al. [23].

All the above publications relate to concrete made with ordinary aggregate. Only a few publications concerning the permeability of shielding concrete with heavyweight mineral aggregates and/or aggregates containing lightweight elements or boron minerals can be found in the literature, Glinicki, M.A. [26-29]. The containment structures are designed to restrict the spread of radiation and radioactive contamination to the environment. Therefore, the permeability of concrete should be included as one of the important mix design criteria [26]. The air permeability and diffusion of moisture in heavyweight concrete containing barite and magnetite aggregate were studied by Kubissa et al. [27]. On the basis of the air permeability index the quality of concrete varied from "very good" to "good", depending on concrete mix design. The gas permeation properties of concrete were found strongly influenced by the degree of saturation of capillary pores. A similar relationship was found by Zhang et al. [28]. A linear relationship between the air permeability index and the relative humidity in pores was obtained in [29] and the effects of heavyweight and hydrogen-bearing aggregates on air permeability index were revealed. 
Binici [30] investigated the heavyweight concrete durability, including among others the resistance to chloride ions. He found that the resistance to the chloride penetration was significantly higher for concrete incorporating barite, both coarse and fine aggregate in comparison to reference concrete with limestone aggregate. The relationship between temperature and carbonation of concrete was found by Zhang et al. [31]. They revealed that the higher the temperature was, the larger the carbonation depth was noticed. At temperatures less than $300^{\circ} \mathrm{C}$, the rate of increase in the carbonation depth was relatively low, but above $450^{\circ} \mathrm{C}$, the carbonation depth increased sharply. At a temperature higher than $600{ }^{\circ} \mathrm{C}$, the carbonation depth of ordinary concrete determined after 28 days increased more than three times (from $7 \mathrm{~mm}$ to $23 \mathrm{~mm}$ ).

The aim of this investigation is to evaluate the impermeability of concrete containing special aggregates with respect to gaseous and liquid media. On the basis of characterization of concrete microstructure, its mechanical and physical properties and its suitability for application in structural elements of nuclear power plants are evaluated.

\section{Materials and Methods}

Blast furnace slag cement (CEM III/A 42.5N LH/HSR/NA) was investigated in the research. As a reference, also low heat, sulfate resistant and low alkali Portland cement CEM I 42.5N (OPC) was used. The specific surface was 4700 and $3800 \mathrm{~cm}^{2} / \mathrm{g}$, respectively. CEM III was characterized by density $2.99 \mathrm{~g} / \mathrm{cm}^{3}$ and CEM I by $3.15 \mathrm{~g} / \mathrm{cm}^{3}$. The water demand was $34 \%$ for CEM III and $28 \%$ for CEM I. Compressive and flexural strength after 28 days was 58.2 and $9.5 \mathrm{MPa}$ and 52.6 and $8.1 \mathrm{MPa}$ for CEM III and CEM I, respectively. The basic cement properties and the detailed chemical and physical properties of cement are given in [32].

The testing program covered concrete mixes with variable magnetite and serpentinite coarse aggregate. Amphibolite coarse aggregate was used as a reference in the concrete mix. A detailed composition of concrete mixes is presented in Table 1, and the properties of the fresh mix are presented in Table 2. As fine aggregate, in all mixes, a siliceous sand of $0-2 \mathrm{~mm}$ was used. The content of sand was $20 \%$, except its content in reference concrete $(30 \%)$. The magnetite to serpentine aggregate ratio was 1:2 (S-MS_2/1 and P-MS_2/1) or 2:1 (S-MS_1/2 and P-MS_1/2). The cement content was constant and amounted to $350 \mathrm{~kg} / \mathrm{m}^{3}$ and water to cement ratio 0.48 . Water reducer based on modified phosphonate and high-range water reducer based on polycarboxylate and modified phosphonate were used.

Specimens $150 \times 150 \times 150 \mathrm{~mm}$ were used to test compressive strength and cylinders $\varnothing=100$ and $\mathrm{h}=200 \mathrm{~mm}$ for chloride ion migration and as well as for porosity accessible for water. Specimens $100 \times 100 \times 100 \mathrm{~mm}$ were cast for $\mathrm{CO}_{2}$ ingress and microstructure analysis. The specimens were conditioned in a climatic chamber at temperature of $20 \pm 2{ }^{\circ} \mathrm{C}$ and relative humidity of $95 \%$ up to 28 days and next in $\mathrm{RH}=55 \pm 5 \%$ (room conditions) up to day of measurement.

The compressive strength was determined on three $150 \times 150 \times 150 \mathrm{~mm}$ specimens for each concrete mix after 7, 28 and 90 days of curing following the standard procedure PN-EN 12390-3:2019 [33].

The chloride ions penetration was tested according to Nordtest Method NT Build 492 [34] using the rapid chloride ion migration test. The value of non-steady-state chloride migration coefficient, $D_{n s s m}$, was determined for a non-steady flux of chloride ions under the action of the external electrical field after 56 and 112 days of curing the concrete specimens and calculated from the Fick's second law. A description of the applied test method is presented in [3]. Each result concerning compressive strength and well as the chloride migration coefficient is an average of three measurements.

The carbonation of concrete was investigated at a constant concentration of carbon dioxide (1\%), at $22{ }^{\circ} \mathrm{C}$ and $60 \%$ relative humidity. The depth of carbonation was tested on one beam from each concrete mix on the freshly split surface with phenolphthalein solution after $0,28,56,90,180$ and 360 days of exposure, according to PN-EN 13295:2005 [35]. The carbonation depth was determined on the average of 20 measurements tested after a prescribed exposure time. 
Table 1. Concrete mix design, $\mathrm{kg} / \mathrm{m}^{3}$.

\begin{tabular}{|c|c|c|c|c|c|c|c|c|c|}
\hline \multicolumn{2}{|c|}{ Constituents } & S-A & S-M & S-MS_1/ & S-MS_2/1 & P-A & P-M & P-MS_1/2 & P-MS_2/1 \\
\hline \multirow{2}{*}{\multicolumn{2}{|c|}{ Cement }} & \multicolumn{4}{|c|}{ CEM III/A LH/HSR/NA } & \multicolumn{4}{|c|}{ CEM I LH/HSR/NA } \\
\hline & & \multicolumn{4}{|c|}{350} & \multicolumn{4}{|c|}{350} \\
\hline \multicolumn{2}{|c|}{ Water } & \multicolumn{4}{|c|}{168} & \multicolumn{4}{|c|}{168} \\
\hline Siliceous sand & $0-2 \mathrm{~mm}$ & 556 & 371 & 371 & 371 & 556 & 371 & 371 & 371 \\
\hline \multirow{2}{*}{$\begin{array}{l}\text { Amphibolite } \\
\text { aggregate }\end{array}$} & $2-8 \mathrm{~mm}$ & 912 & 0 & 0 & 0 & 912 & 0 & 0 & 0 \\
\hline & $8-16 \mathrm{~mm}$ & 507 & 0 & 0 & 0 & 507 & 0 & 0 & 0 \\
\hline \multirow{3}{*}{$\begin{array}{l}\text { Serpentine } \\
\text { aggregate }\end{array}$} & $0-2 \mathrm{~mm}$ & 0 & 0 & 0 & 0 & 0 & 0 & 0 & 0 \\
\hline & $2-8 \mathrm{~mm}$ & 0 & 0 & 485 & 485 & 0 & 0 & 485 & 485 \\
\hline & $8-16 \mathrm{~mm}$ & 0 & 0 & 0 & 485 & 0 & 0 & 0 & 485 \\
\hline \multirow{2}{*}{$\begin{array}{l}\text { Magnetite } \\
\text { aggregate }\end{array}$} & $0-5 \mathrm{~mm}$ & 0 & 839 & 772 & 895 & 0 & 839 & 772 & 895 \\
\hline & $0-16 \mathrm{~mm}$ & 0 & 1846 & 1018 & 0 & 0 & 1846 & 1018 & 0 \\
\hline $\mathrm{WR}^{*}$ & \multirow{2}{*}{ (\% of c. mass) } & 0.58 & 1.02 & 1.49 & 2.18 & 0.39 & 0.67 & 1.51 & 0.97 \\
\hline HRWR ** & & 0 & 0 & 0 & 0 & 0 & 0 & 0 & 0.31 \\
\hline
\end{tabular}

Table 2. Properties of fresh mix.

\begin{tabular}{ccccccccc}
\hline Properties & S-A & S-M & S-MS_1/2 & S-MS_2/1 & P-A & P-M & P-MS_1/2 & P-MS_2/1 \\
\hline $\begin{array}{c}\text { Slump, } \\
\text { mm }\end{array}$ & 80 & 200 & 80 & 80 & 70 & 80 & 100 & 60 \\
\hline Bulk density, $\mathrm{kg} / \mathrm{m}^{3}$ & 2440 & 3579 & 3145 & 2781 & 2459 & 3500 & 3084 & 2735 \\
\hline
\end{tabular}

Analysis of the concrete microstructure was performed on thin sections cut from concrete prisms. For this purpose, the fluorescent epoxy impregnated thin sections were prepared according to [24]. The concrete specimens were cut in smaller pieces $(40 \times 50 \mathrm{~mm})$, which were then vacuum impregnated with a low viscous resin together with yellow fluorescent dye. The thin section subjected to further microscopic analysis was characterized by thicknesses of $20 \pm 2 \mu \mathrm{m}$. Thin section analysis was performed using the optical polarizing microscope Olympus BX51 with a digital camera. The polarized light (PPL), crossed polarized light (XPL), and also with lambda plate and UV light were applied for thin sections analysis.

A mercury intrusion porosity (MIP) test was also executed to evaluate the differences in pore content and pore size distribution. MIP measurements were carried out using cores with diameter $9 \mathrm{~mm}$ and length $25 \mathrm{~mm}$ drilled from concrete specimens. Drilled specimens were crushed and then a cement mortar was separated to further measurements. All investigated specimens were characterized by the same volume and were smaller than $2 \mathrm{~cm}^{3}$, limited by the volume of the measurement container. The analyzed specimens were dried until a constant weight at $35^{\circ} \mathrm{C}$ and then they were kept in tightly closed containers to avoid a humidity exchange with the environment. Quantachrome POREMASTER 60 mercury porosimeter, which was able to detect the pores up to $5 \mathrm{~nm}$ with the maximum pressure of $414 \mathrm{MPa}$, was used. The accuracy of measurement was $0.001 \mathrm{PSI}$, which corresponds to $5 \mathrm{~nm}$ resolution. The volume of intruded mercury was measured with accuracy $0.0001 \mathrm{~cm}^{3} / \mathrm{g}$. A cement matrix without aggregate was separated from three cores from each concrete after 120 days of water curing.

Two cores from each concrete mix (100 $\pm 2 \mathrm{~mm}$ diameters and $50 \pm 2 \mathrm{~mm}$ height) were used to assess the open porosity according to NF P18-459: 2010 [36]. They were vacuumed, saturated with tap water and weighed in three water saturation states: fully saturated and weighted with hydrostatic balance, fully saturated and weighted with an analytical balance, and dried to constant mass at $105^{\circ} \mathrm{C}$. Based on the obtained results, the porosity available for water was determined. 


\section{Results}

\subsection{Compressive Strength}

The results of the 7,28 and 90 days of compressive strength for concrete made with various coarse aggregates and both CEM I and CEM III are presented in Figure 1.
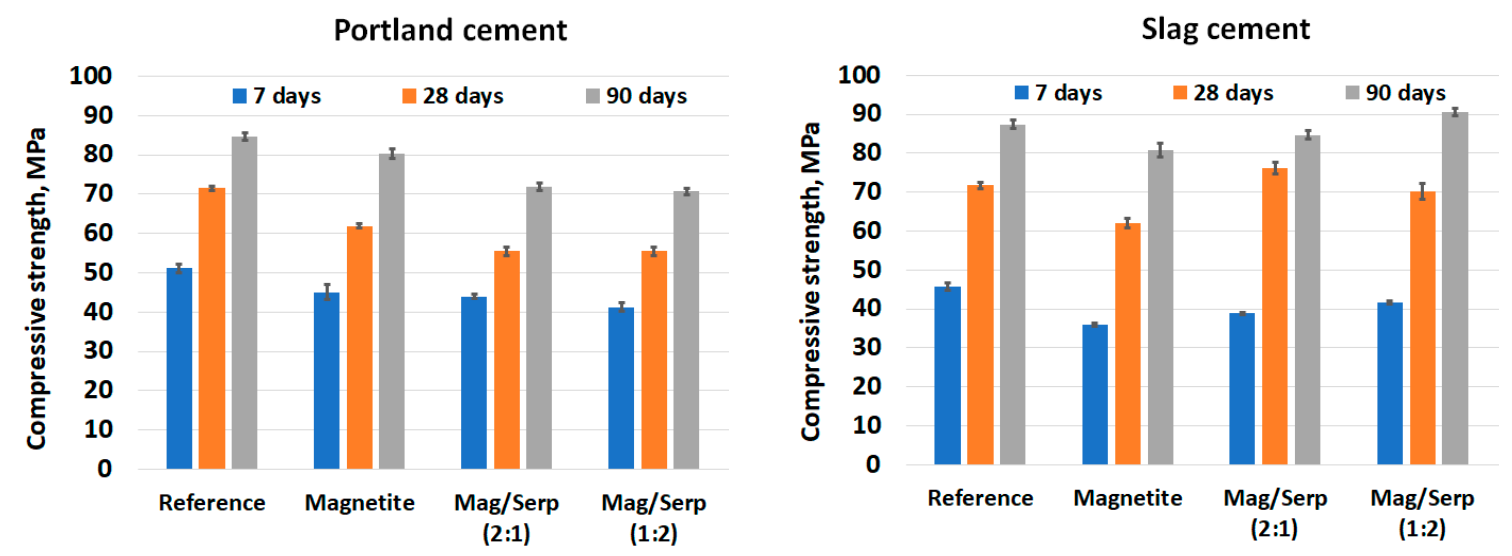

Figure 1. Compressive strength of concrete tested after 7, 28 and 90 days of curing.

The highest value of compressive strength tested after 7,28 and 90 days for concrete made with CEM I achieved reference concrete made with amphibolite aggregate, 51, 71 and $85 \mathrm{MPa}$, respectively. In concretes containing CEM I and special aggregate, the highest compressive strength, regardless of curing time, was achieved for concrete with magnetite aggregate: 45, 62 and $80 \mathrm{MPa}$ after 7, 28 and 90 days. Concretes made with serpentine aggregate were characterized by lower values of compressive strength, although very close to the previous one. The change in magnetite and serpentine content (P-MS_1/2 and P-MS_2/1) did not affect the compressive strength values significantly. All concretes made with CEM I belonged to the strength class C55/67 (after 90 days).

In concrete containing CEM III cement, the beneficial influence of a special aggregate type on compressive strength was visible. The highest values of compressive strength were achieved by concretes containing a mixture of magnetite and serpentine aggregate, S-MS_1/2 and S-MS_2/1. After 90 days of curing, they were characterized by 85 and $91 \mathrm{MPa}$. A similar value was achieved by reference concrete, $87 \mathrm{MPa}$, which placed them in the compressive strength class C70/85. Slightly lower values of compressive strength were achieved for concretes made with pure magnetite aggregate, S-M-81 MPa (the compressive strength class C60/75).

\subsection{The Nonsteady Chloride Migration Coefficient}

After 56 and 120 days of curing, the nonsteady chloride migration coefficient $D_{n s s m}$, was investigated, (Figure 2). Four classes of the concrete resistance to chloride ions penetration were applied, Glinicki, M.A., et al. [3]: very good $\left(D_{n s s m}<2 \times 10^{-12} \mathrm{~m}^{2} / \mathrm{s}\right)$, good $\left(2 \div 8 \times 10^{-12} \mathrm{~m}^{2} / \mathrm{s}\right)$, acceptable $\left(8 \div 16 \times 10^{-12} \mathrm{~m}^{2} / \mathrm{s}\right)$ and unacceptable $\left(D_{n s s m}>16 \times 10^{-12} \mathrm{~m}^{2} / \mathrm{s}\right)$. 
(a)

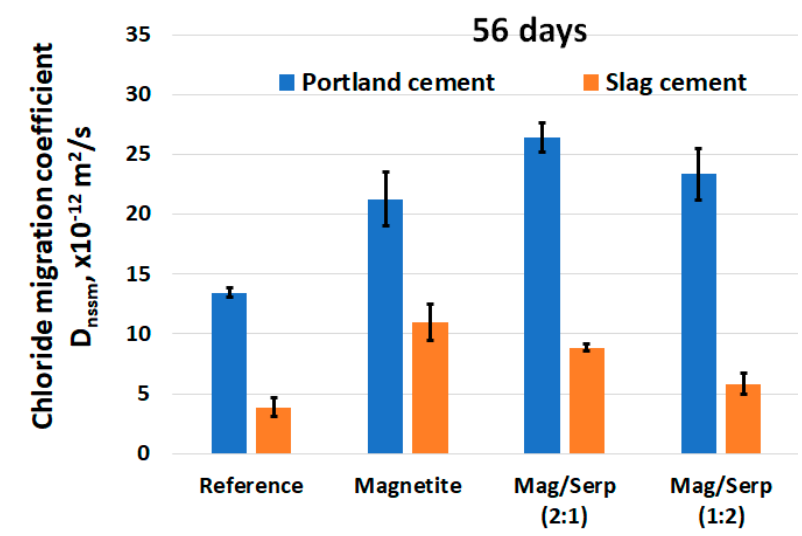

(b)

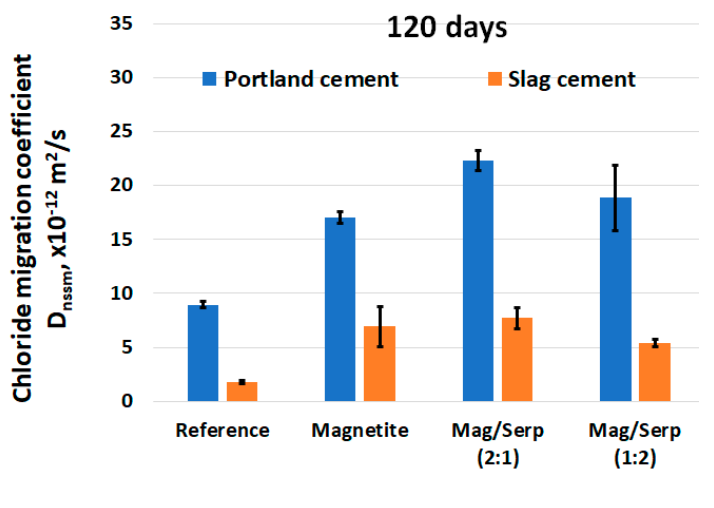

Figure 2. Influence of cement type on the chloride ions migration coefficient specified after: (a) 56 and (b) 120 days of curing.

In all analyzed series, the influence of CEM III in comparison to CEM I on the chloride ions migration coefficient was clearly visible. A significant increase in the resistance of concrete to the penetration of chloride ions was observed, after 56 days as well as after 120 days of curing. The use of slag cement was found to reduce the chloride migration coefficient after 120 days for even two categories of chloride ions migration resistance.

The reference concrete contained slag cement achieved the lowest values of $D_{n s s m}, 3.8 \times 10^{-12} \mathrm{~m}^{2} / \mathrm{s}$ after 56 days and $1.7 \times 10^{-12} \mathrm{~m}^{2} / \mathrm{s}$ after 120 days which classifies it into good and very good classes of the concrete resistance to chloride ions penetration. Concrete S-MS_2/1 achieved the lowest value of $D_{n s s m}$ in the group of concretes with slag cement and special aggregate. The nonsteady chloride migration coefficient was relatively stable and achieved $5.8 \times 10^{-12} \mathrm{~m}^{2} / \mathrm{s}$ after 56 days and $5.4 \times 10^{-12} \mathrm{~m}^{2} / \mathrm{s}$ after 120 days (good class). After 120 days of curing, concretes with magnetite (S-M) and magnetite/serpentine with a ratio of 2:1 (S-MS_1/2) were characterized by similar values of $D_{n s s m}$ and revealed good resistance to chloride ingress, respectively $7.0 \times 10^{-12} \mathrm{~m}^{2} / \mathrm{s}$ and $7.7 \times 10^{-12} \mathrm{~m}^{2} / \mathrm{s}$.

In concretes containing Portland cement, differences between 56 and 120 days of curing are relevant for the chloride migration coefficient. After 56 days, all concrete containing special aggregate were characterized by high $D_{n s s m}$ coefficient, from 21.3 to $31.2 \times 10^{-12} \mathrm{~m}^{2} / \mathrm{s}$, and after 120 days from 17.0 to $25.1 \times 10^{-12} \mathrm{~m}^{2} / \mathrm{s}$. All the above concretes were assigned to class unacceptable, however among them, concrete with magnetite aggregate showed the best resistance to chloride ions penetration, and concrete with serpentine aggregate the worst. The chloride ion migration coefficient increased with increasing the content of serpentine aggregate. Reference concrete with amphibolite aggregate both after 56 and 120 days achieved acceptable class, respectively 13.5 and $9.1 \times 10^{-12} \mathrm{~m}^{2} / \mathrm{s}$.

\subsection{Depth of Carbonation}

The results of the carbonation depth of concrete measured until 360 days are presented in Figure 3. As it was expected, the depth of carbonation increased, along with the age of exposure. None of the tested concretes except reference one with Portland cement and amphibolite aggregate (P-A) did not show a tendency to achieving the maximum depth of carbonation. The effect of cement type on the carbonation of concrete was clearly visible. The lowest value of the carbonation depth was achieved by concrete with Portland cement, and the highest results for carbonation depth were observed in concretes containing the slag cement. Among the concretes with slag cement and special aggregate, the highest depth of carbonation was achieved by concrete S-M with magnetite aggregate, $13.5 \mathrm{~mm}$ after one year of exposure in $1 \% \mathrm{CO}_{2}$. Similar but slightly lower results were achieved by concrete with magnetite + serpentine S-MS_1/2-13.4 mm. In concrete with slag cement, the increase of serpentine 
aggregate caused an increase in carbonation depth, while in concrete with Portland cement the trend was opposite, the more serpentine aggregate the smaller the carbonation depth.

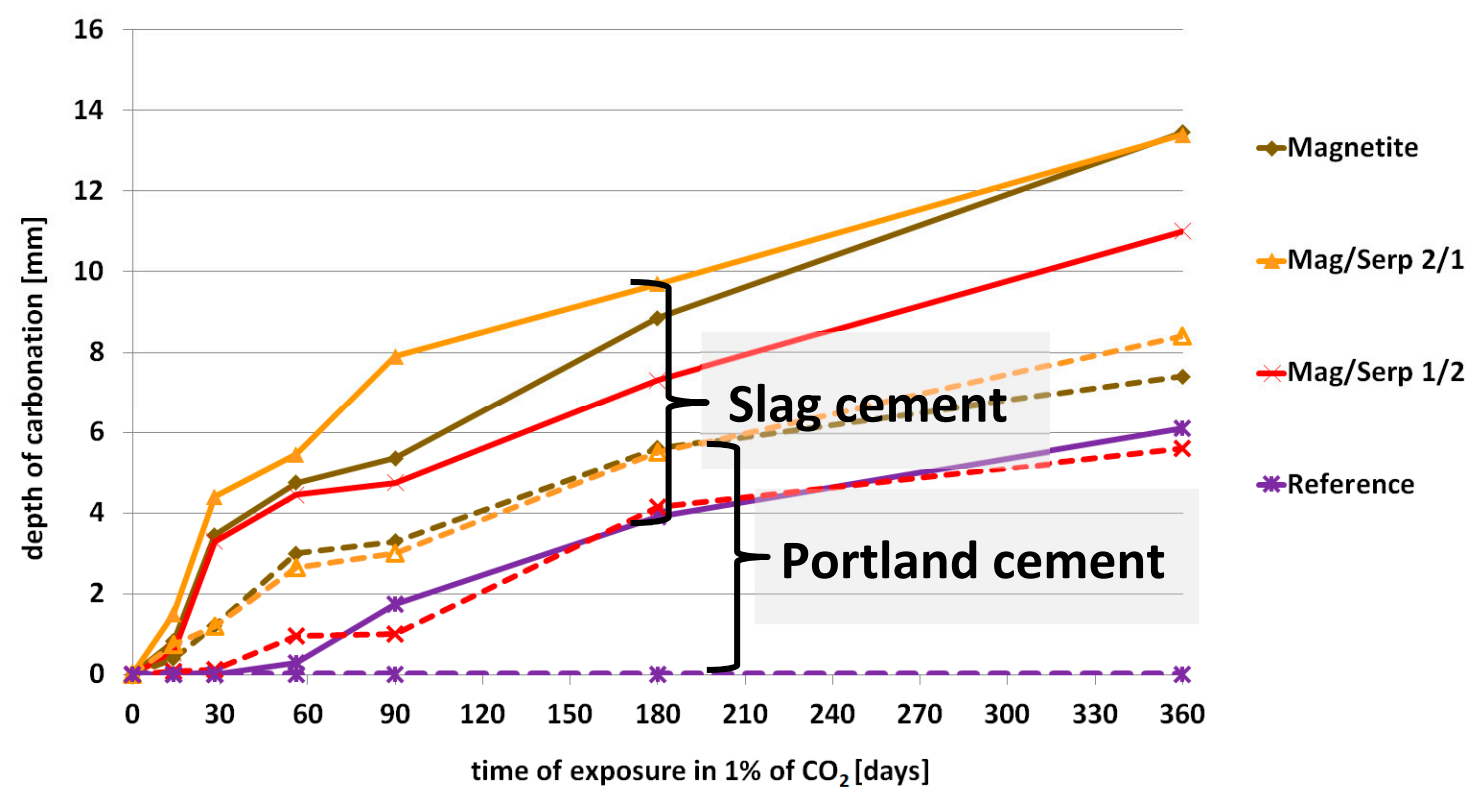

Figure 3. The results of the carbonation test after $0,28,56,90,180,270$ and 360 days in $1 \% \mathrm{CO}_{2}$; the solid line corresponds to concrete with slag cement, the dashed line corresponds to concrete with Portland cement.

It is also worth noting that the progress of carbonation in concretes with slag cement and special aggregates occurred much faster than in the case of concrete with Portland cement. After 28 days of exposure in carbon dioxide the values of the carbonation depth were three times higher for concrete made with magnetite aggregate and more than twenty times higher for concrete made with serpentine aggregate compared to those with Portland cement.

\subsection{Concrete Microstructure}

All concretes were analyzed on thin sections in transmitted light to evaluate their microstructure. Digital images of thin sections $(25 \times 45 \mathrm{~mm})$ consisting of aggregate grains and surrounding cement matrix with air voids filled by resin are presented in Figure 4 . The separate images $(1.5 \times 2 \mathrm{~mm})$ were automatically acquired and assembled into one image, which was then subjected to further analysis.

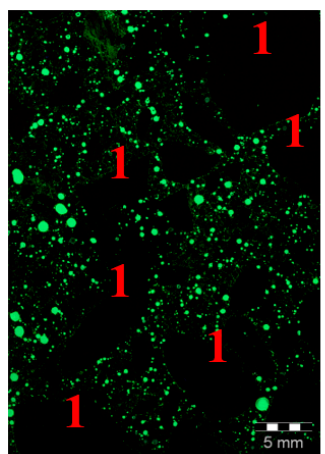

magnetite, S-M

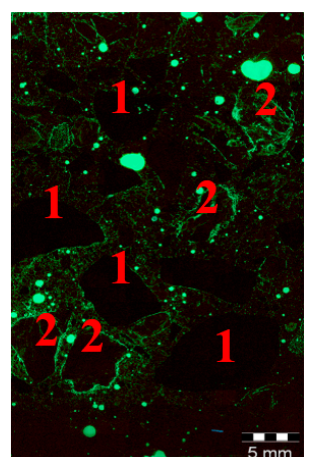

magnetite/serpentine 2:1, S-MS_2/1

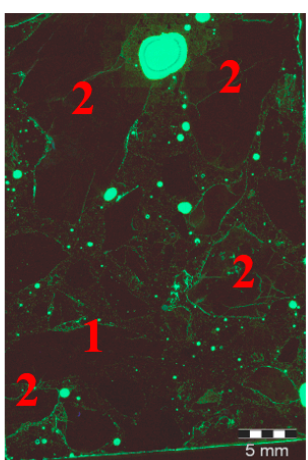

magnetite/serpentine 1:2, S-MS_1/2

Figure 4. Microstructure of concrete containing slag cement on thin sections in UV light, 1- magnetite aggregate, 2-serpentine aggregate, air voids filled by resin visible in green in UV light, scale bar $=5 \mathrm{~mm}$. 
Uniform distribution of the coarse aggregate was visible in all concretes containing slag cement and special aggregates. Concrete made with magnetite aggregate only was characterized by a higher content of smaller air voids (max. $0.5 \mathrm{~mm}$ ) than other concretes. Figure 4 shows the dependence, the more serpentine aggregate and the less magnetite aggregate in concrete with slag cement, the lower content of smaller air voids and the higher content of the individual, larger entrapped air.

The microscopic analysis of thin sections revealed that the zone around the serpentine aggregate differed from the zones surrounding the other aggregates (Figures 4 and 5). The zones of increased porosity were clearly visible on thin sections observed in plane-polarized light (PPL) as well as in UV light. Detailed microscopic analysis showed that the porous zone around the serpentinite aggregate was higher than in the magnetite or amphibolite aggregate. The cement type slightly affects the zone of discontinuity in concrete with serpentine aggregate. The width of that zone was from about 50 to $80 \mu \mathrm{m}$ in concrete with Portland cement and from about 50 to $100 \mu \mathrm{m}$ in concrete with slag cement.

(a)
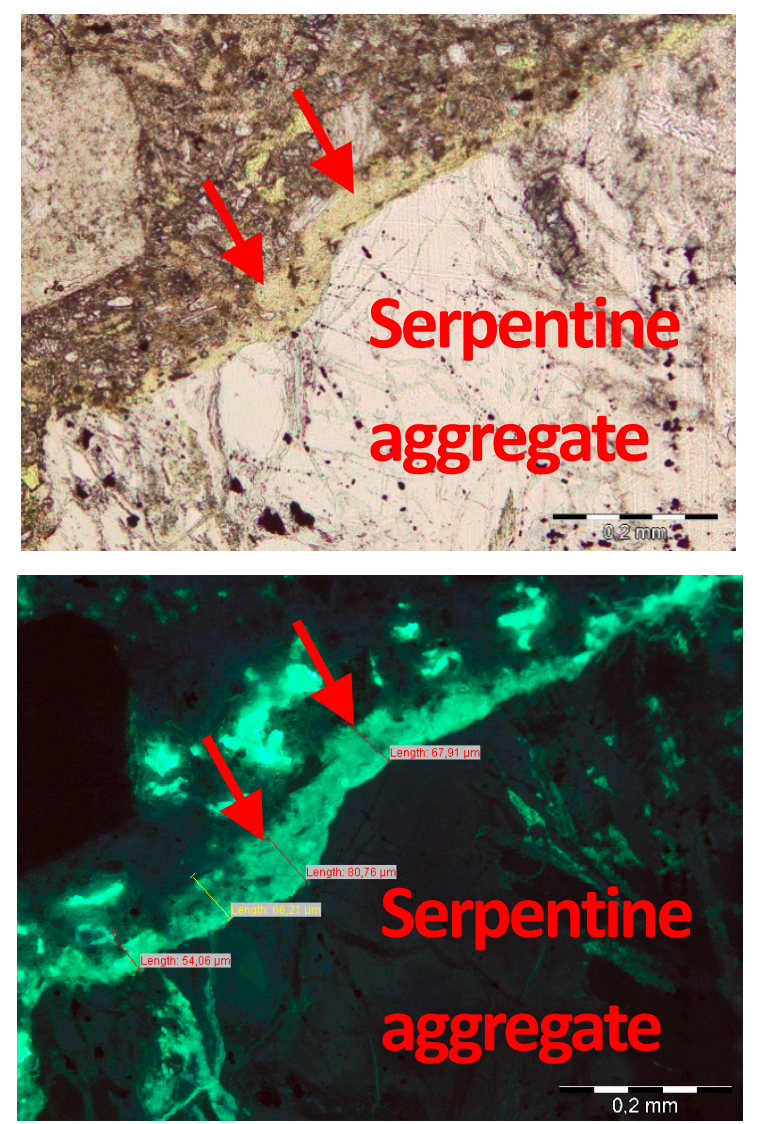

(b)
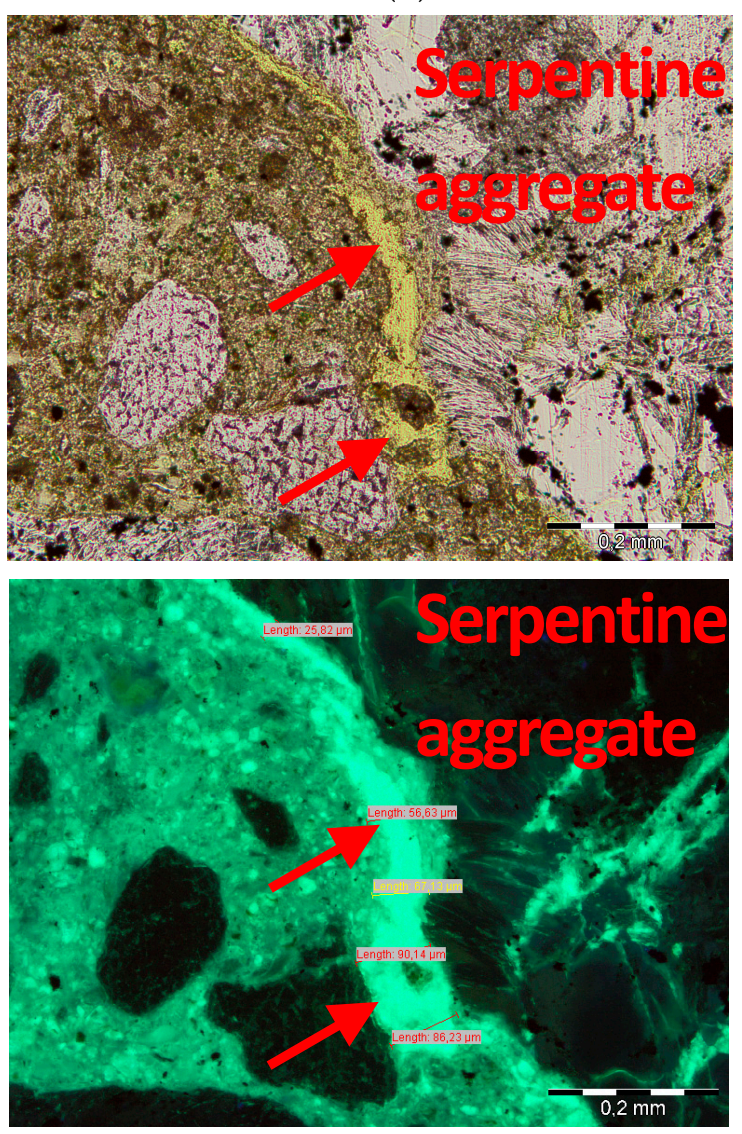

Figure 5. The zone of increased porosity around the serpentine aggregate in concrete with: (a) slag cement, (b) Portland cement; thin section in PPL and UV light, scale bar $=0.2 \mathrm{~mm}$.

\subsection{Porosity}

\subsubsection{Mercury Intrusion Porosity Tests}

Results of MIP measurement on cement paste taken from analyzed concretes with two types of cement are presented in Figures 6 and 7. The total volume of pores was similar, within the range $0.023-0.030 \mathrm{~cm}^{3} / \mathrm{g}$ for concrete with slag cement and $0.024-0.047 \mathrm{~cm}^{3} / \mathrm{g}$ for concrete with Portland cement. 
(a)

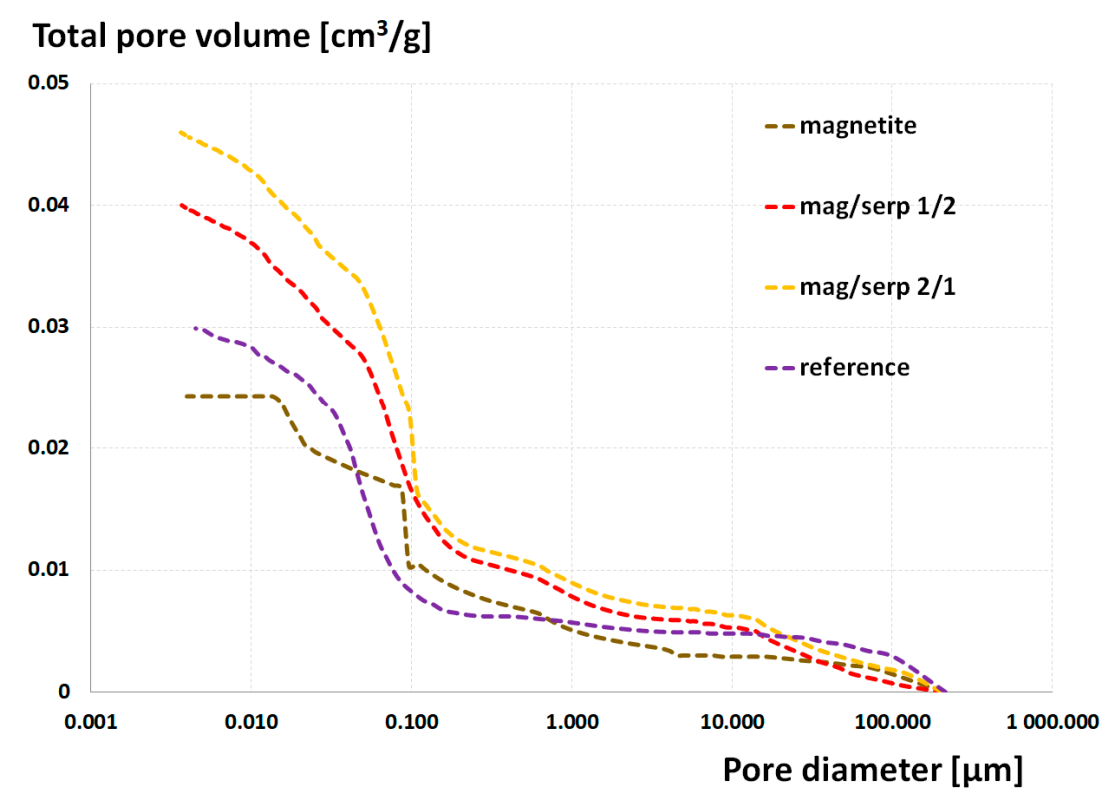

(b)

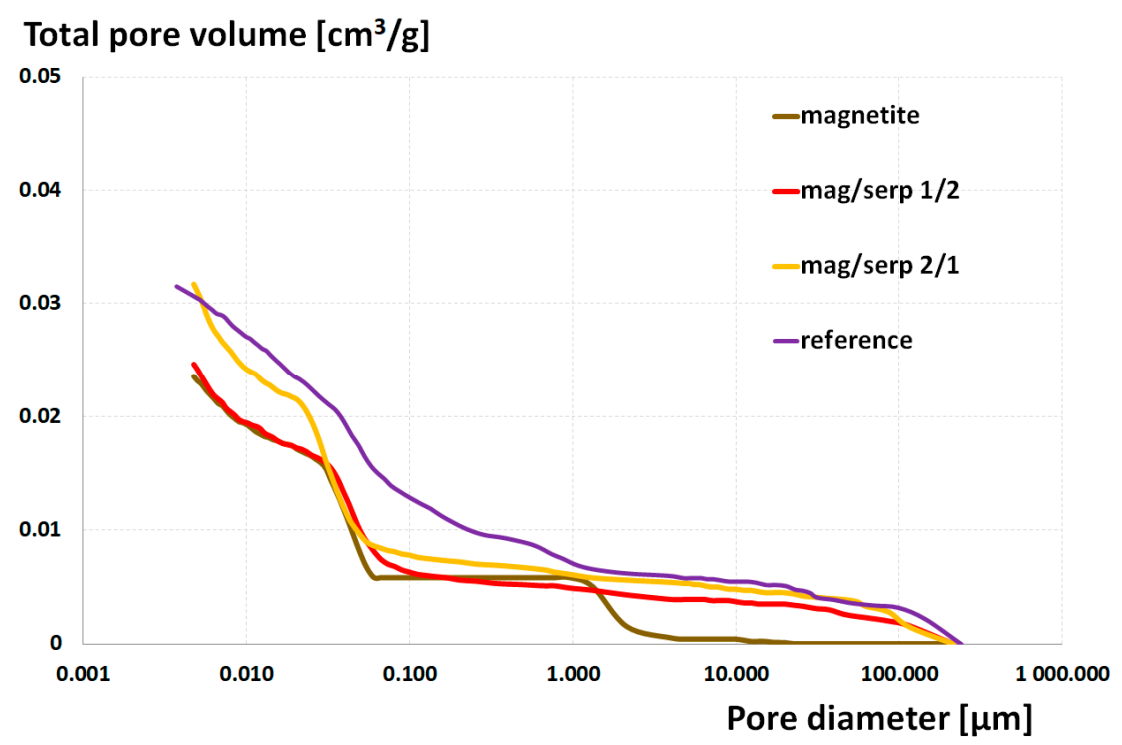

Figure 6. Total pore volume by mercury intrusion porosity (MIP) measurement: (a) Portland cement, (b) slag cement.

The total pore volume for concrete made with slag cement and various magnetite aggregate content was similar, regardless of the amount of this aggregate. It was $0.022 \mathrm{~cm}^{3} / \mathrm{g}$ for concrete with magnetite aggregate (S-M), $0.023 \mathrm{~cm}^{3} / \mathrm{g}$ for magnetite/serpentinite ratio $1: 2$ (S-MS_1/2) and $0.029 \mathrm{~cm}^{3} / \mathrm{g}$ for magnetite/serpentinite ratio 2:1 (S-MS_2/1). The content of total pore volume for reference concrete (B19) was $0.030 \mathrm{~cm}^{3} / \mathrm{g}$ (Figure $6 \mathrm{~b}$ ).

A much more pronounced effect of the aggregate on the total pore volume content was visible in concretes containing Portland cement. The lowest value of the total pore volume achieved concrete with magnetite aggregate (P-M) $0.024 \mathrm{~cm}^{3} / \mathrm{g}$, lower than reference concrete (P-A) $0.029 \mathrm{~cm}^{3} / \mathrm{g}$, subsequently concrete with magnetite/serpentine in ratio 1 to 2 (P-MS_1/2) and 2 to 1 (P-MS_2/1), respectively $0.039 \mathrm{~cm}^{3} / \mathrm{g}$ and $0.045 \mathrm{~cm}^{3} / \mathrm{g}$ (Figure $6 \mathrm{a}$ ). 
(a)

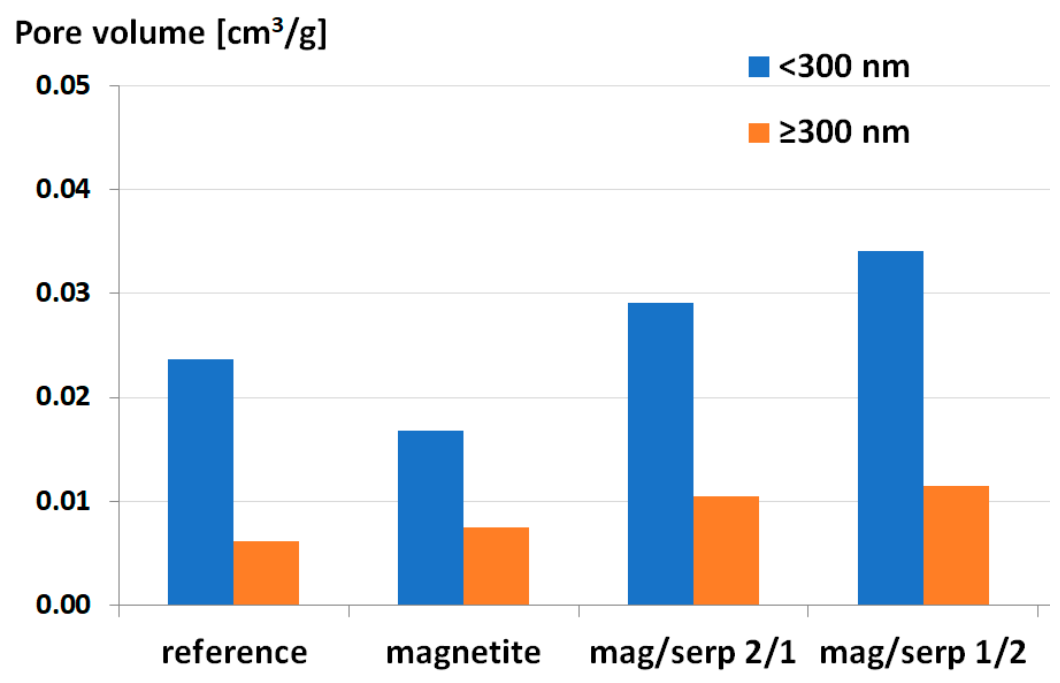

(b)

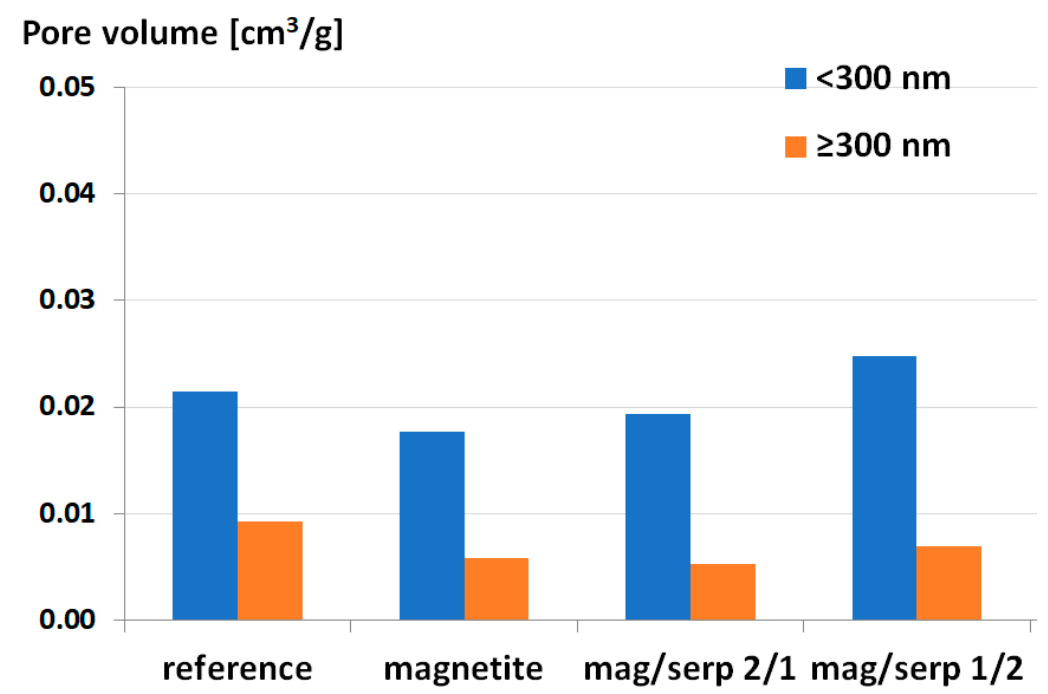

Figure 7. Pore volume for the most numerous pores below $300 \mathrm{~nm}$ by MIP measurement: (a) Portland cement, (b) slag cement.

Pore size distribution analyzed revealed the largest number of pores within the range below $300 \mathrm{~nm}$. It influenced the total pore volume (Figure 7). Concretes containing slag cement (S-M, S-MS_1/2, S-MS_2/1) were characterized by the lowest volume of capillary pores $>300 \mathrm{~nm}$ (Figure $7 \mathrm{~b}$ ). The volume was in the range of $0.005-0.007 \mathrm{~cm}^{3} / \mathrm{g}$, which constituted $30-45 \%$ less than the volume of capillary pores for reference concrete (S-A). Concretes with Portland cement were characterized by the highest volume of capillary pores $\left(>300 \mathrm{~nm}\right.$ ) with range $0.007-0.011 \mathrm{~cm}^{3} / \mathrm{g}\left(\mathrm{P}-\mathrm{M}, \mathrm{P}-\mathrm{MS} \_1 / 2, \mathrm{P}-\mathrm{MS} \_2 / 1\right)$, which was $20-110 \%$ more than reference concrete (P-A) with amphibolite aggregate (Figure 7a).

Regardless of the cement type, the increase in magnetite aggregate content in concrete influenced the decrease in the total pore volume. A decrease in the total pore volume measured by MIP was observed with an increase in the volume of magnetite aggregate.

\subsubsection{Porosity Accessible to Water}

The results of the porosity accessible to water are presented in Figure 8. The lowest values of porosity were achieved by the reference concrete, with Portland cement $11.0 \%$ and with slag cement 
$11.4 \%$. Use of special aggregates, both magnetite and serpentine increased open porosity for all cement types compared to reference concrete with amphibolite aggregate. The values of the porosity accessible to water were similar for concrete made with Portland cement and special aggregate, about $12.5 \pm 0.3 \%$. However, they differed when slag cement was used. In this group of concretes, the lowest value of porosity achieved concrete S-MS_1/2, with a magnetite/serpentine ratio of $1: 2-12.8 \%$, and the highest concrete S-MS_2/1 with a magnetite to serpentine ratio of 2:1-14.4\%.

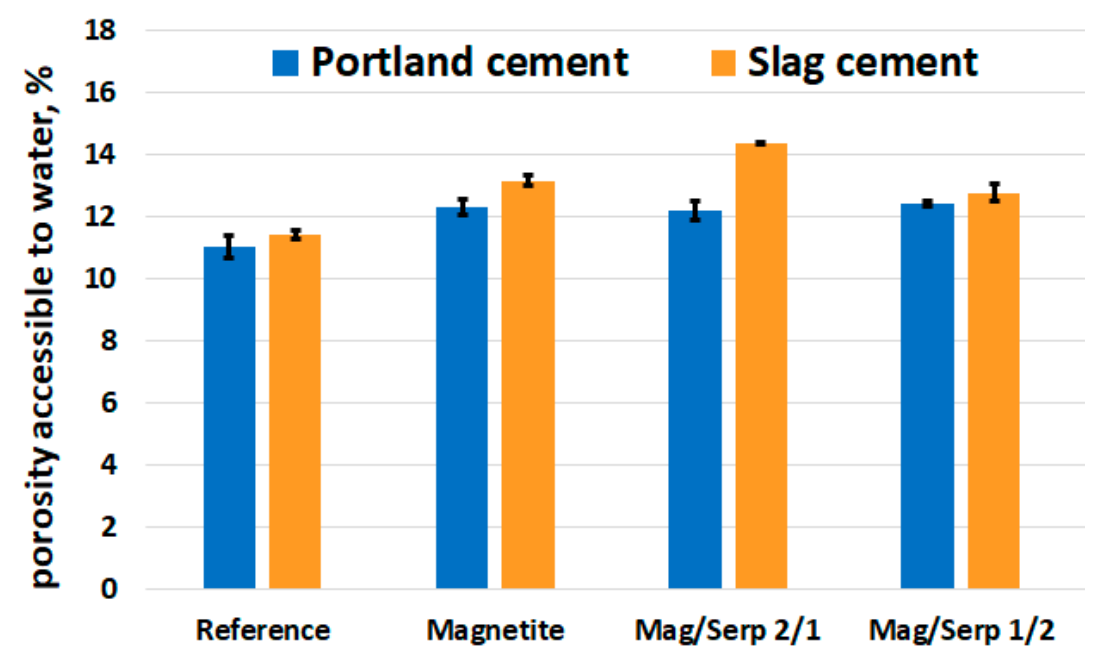

Figure 8. Porosity accessible to water measured after 120 days of curing.

\section{Discussion}

All obtained results regarding the permeability of the analyzed concretes: chloride migration, carbonation, pore size distribution and porosity accessible for water, as well as the results of compressive strength and microstructure are compatible with each other and complementary.

It is known from the literature that hydration of slag cement is slower than ordinary Portland cement. Concrete made with CEM III/A cement is characterized by delayed setting, Lura, P., et al. [37]. The research conducted by Hager et al. [38] revealed that slag cement influenced the compressive strength of 90-day concrete. In their research concrete with slag cement was characterized by higher compressive strength on average by $10 \mathrm{MPa}$ for both basalt and river bed aggregate concrete in comparison to Portland cement. Kubissa et al. [27] investigated magnetite aggregate and blended cement with ground granulated blast furnace slag. They showed that the use of CEM II/B-S cement resulted in a significant increase in concrete compressive strength at the age of about 2 years, up to $45 \%$. The influence of slag cement on the long-term compressive strength of the investigated concretes confirmed partly earlier results. The influence of CEM III/A cement in reference concrete with amphibolite aggregate was negligible. The 90 days compressive strength for reference concrete was similar, $85 \mathrm{MPa}$ for Portland cement and $87 \mathrm{MPa}$ for slag cement. After the same maturity period, the values of compressive strength for concrete made with only magnetite, regardless of the cement used, were lower than reference concrete but similar. It was 80.2 and $80.8 \mathrm{MPa}$ for magnetite concrete with Portland and slag cement. However, the effect of the type of cement on the compressive strength of concrete containing a mixture of magnetite and serpentine aggregate was visible. Higher compressive strength determined after 90 days of curing were obtained when using slag cement, 84.6 MPa for S-MS_1/2 and 90.6 MPa for S-MS_2/1. When using Portland cement, concretes containing magnetite and serpentine in proportions of 1:2 and 2:1 were characterized by similar compressive strength, 71.9 and $70.7 \mathrm{MPa}$.

The influence of special aggregate on concrete compressive strength was investigated by [39,40]. Horszczaruk et al. [39] revealed that the use of magnetite aggregate instead of gravel and river sand improved mechanical properties, compressive (about $10 \mathrm{MPa}$ ) and splitting (about 1.2 $\mathrm{MPa}$ ) strength 
of concrete made with CEM I and 10\% of silica fume. Petrounias et al. [40] analyzed three groups of aggregate: serpentine, diabase-gabbro and albitite. The compressive strength of concrete with CEM II 32.5N cement showed the lowest value for concrete with serpentine aggregate. The conducted research showed that concrete made with magnetite aggregate achieved higher compressive strength after 90 days in comparison to concrete made with serpentine aggregate. The difference was small and amounted to $5 \mathrm{MPa}$ for concrete with Portland cement and $3 \mathrm{MPa}$ for concrete with slag cement. The obtained results of compressive strength with serpentine aggregate significantly exceed the values given in the report, Almenas, K., et al. [41]. In the Lithuanian NPP, at Ignalina, compressive strength of serpentine concrete which was used as the shielding concrete achieved $40 \div 62.5 \mathrm{MPa}$.

Plotting the porosity accessible to water versus the compressive strength of concrete reveals some degree of correlation for two types of cement. The tendency to slightly decrease the porosity available for water with the increase in the compressive strength of concrete with Portland cement and a much stronger relationship for slag cement was demonstrated. A similar relationship between the compressive strength and the water absorption at 28 days of concrete made with CEM I, CEM II/B-S and CEM III/A cements achieved Giergiczny et al. [42].

The relationship of the porosity accessible to water and both, the depth of carbonation and nonsteady chloride migration coefficient is presented in Figures 9 and 10. As in the case of compressive strength, the relationship of the porosity accessible for water and the resistance of concrete to carbonation is definitely more pronounced for concretes with slag cement. Higher $\mathrm{CO}_{2}$ penetration depth values corresponded to a higher available porosity accessible for water values for concrete containing slag cement. This relationship is confirmed in the literature, Hager, I., et al. [38,43]. Concrete with slag cement was characterized by lower Cembureau permeability [44] for natural aggregate both crushed and uncrushed (gravel) in comparison to Portland cement, Hager, I., et al. [38]. The application of heavyweight and hydrous aggregates in concrete was investigated by Jaskulski et al. [43]. They revealed that concretes with magnetite and serpentine aggregate achieved an open porosity value from 12.2 to $13.3 \%$. The increase in the open porosity was $1.2-2.3 \%$ in comparison with concrete containing amphibolite aggregate.

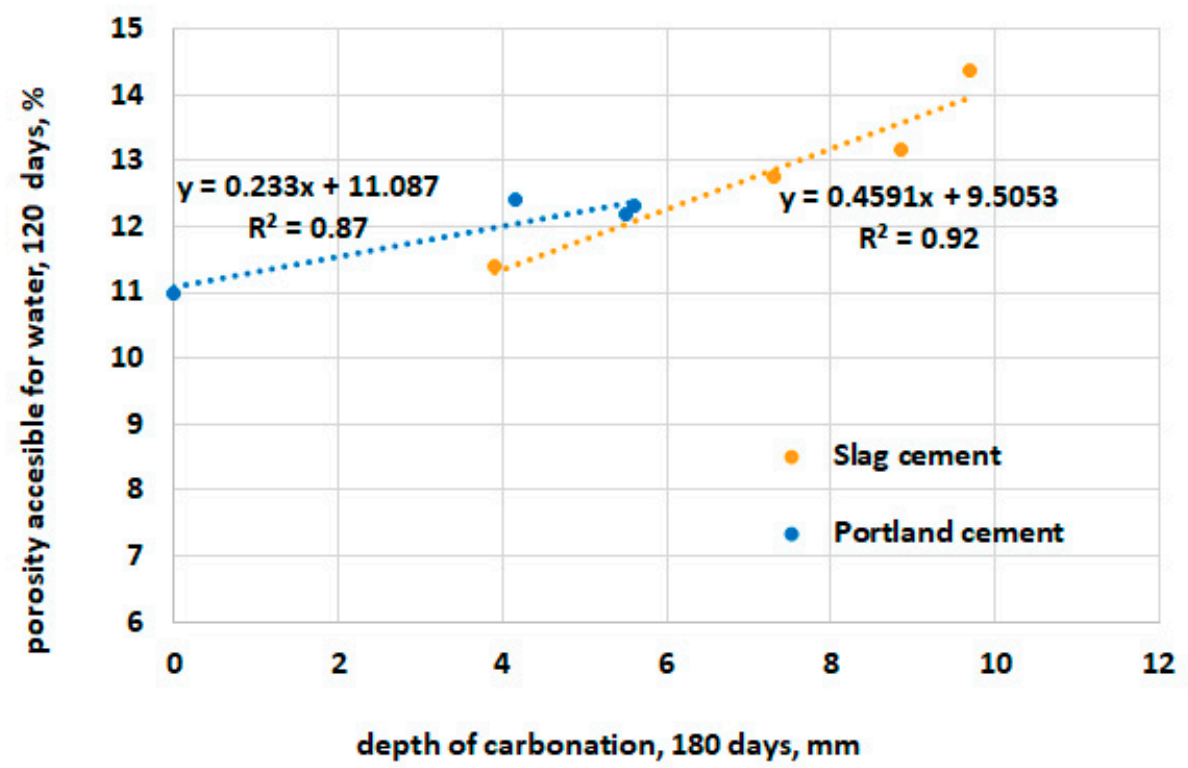

Figure 9. Relationship between the porosity accessible to water and depth of carbonation.

The total pore volume evaluated using mercury intrusion porosimetry was influenced by the content of magnetite aggregate in concrete containing slag cement. In Figure 11, the relationship between the relative content of magnetite aggregate and the total pore volume is presented. The total pore volume is linearly decreasing with increasing content of magnetite aggregate and a simultaneous 
decrease in the content of serpentine aggregate. The porosity is systematically lower for slag cement concrete. Such results demonstrate the beneficial effects of using slag cement and various content of crushed magnetite aggregate in radiation shielding concrete of low permeability.

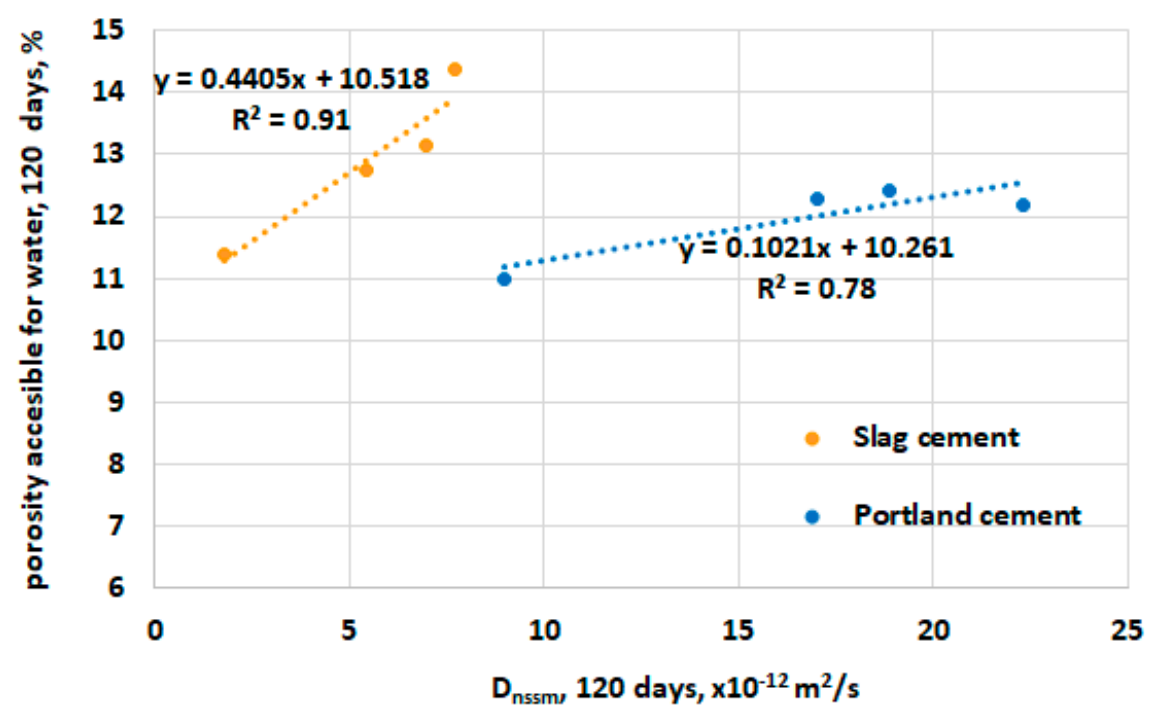

Figure 10. Relationship between the porosity accessible to water and non-steady-state chloride migration coefficient after 120 days of concrete curing.

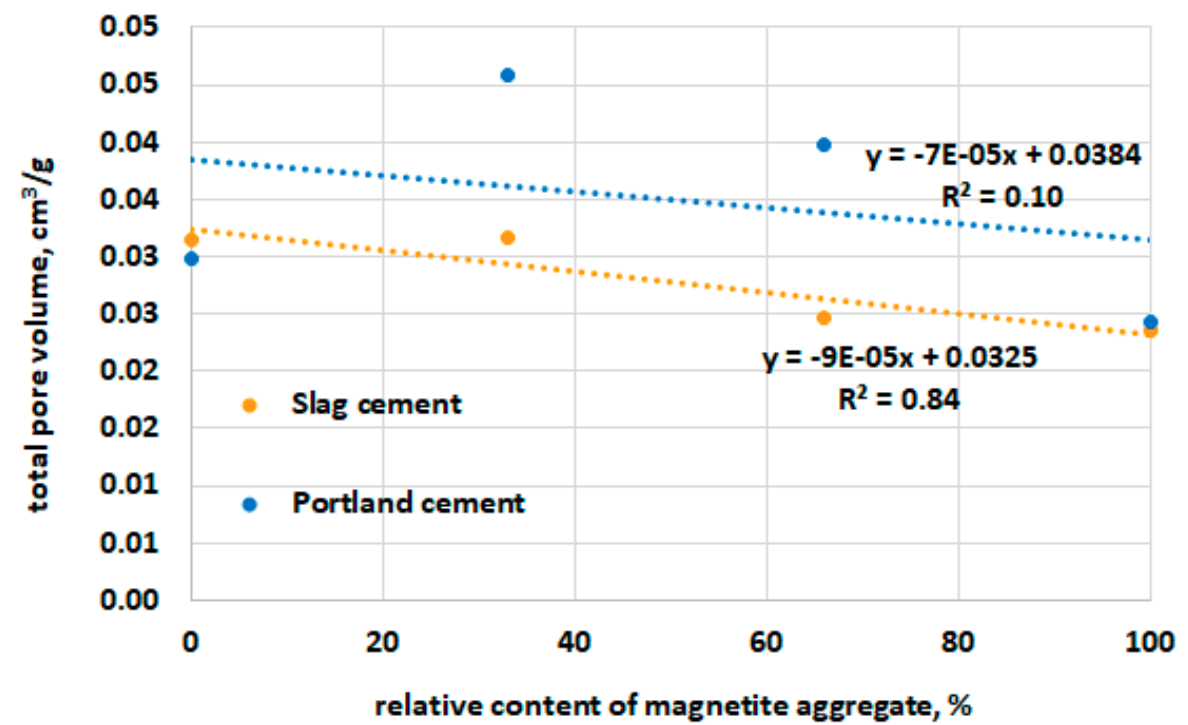

Figure 11. The relationship between the relative content of magnetite aggregate and the total pore volume.

\section{Conclusions}

The following conclusions can be drawn:

- Use of slag cement CEM III/A in concrete containing magnetite and serpentine aggregates resulted in the substantial improvement of the compressive strength in comparison with Portland cement concrete. The attained strength class was C70/85 and C55/67, respectively.

- The application of slag cement was found to reduce the chloride ingress, regardless of the special aggregate use. In regard to Portland cement concrete, the coefficient of chloride migration $D_{\text {nssm }}$ decreased from $17 \div 25 \times 10^{-12} \mathrm{~m}^{2} / \mathrm{s}$ to $5 \div 8 \times 10^{-12} \mathrm{~m}^{2} / \mathrm{s}$ at the age of 120 days. 
- The effect of cement type on the concrete carbonation depth was clearly demonstrated: the lowest carbonation depth $(4.5 \div 7.0 \mathrm{~mm})$ was achieved for Portland cement concrete and the highest $(11.0 \div 13.9 \mathrm{~mm})$ for slag cement concrete.

- The type of cement did not influence the uniformity of coarse aggregate distribution and microstructural homogeneity of hardened cement paste in concrete containing special aggregates.

- The total pore volume evaluated using mercury intrusion porosimetry was influenced by the type of special aggregate. A linearly decreasing relationship was found between the relative content of magnetite aggregate and the total pore volume in concrete containing slag cement. The smallest total pore volume $\left(0.024 \mathrm{~cm}^{3} / \mathrm{g}\right)$ was found for concrete with the highest content of magnetite aggregate and both cement types. Serpentine coarse aggregates caused an increase in total pore volume in comparison to concrete with magnetite aggregate.

- The use of magnetite and serpentine aggregates resulted in an increase in the concrete porosity accessible to water by 1 to 3\%, in concrete with Portland and slag cement, respectively.

Author Contributions: Conceptualization, D.J.-N., M.A.G.; methodology, K.B., D.J.-N., M.D.; investigation, K.B., D.J.-N., M.D.; writing—original draft preparation, D.J.-N., M.A.G.; writing—review and editing, D.J.-N., M.A.G., M.D.; All authors have read and agreed to the published version of the manuscript.

Funding: The financial support of Project no PBSII/A2/15/2014 and V4-Korea/2/2018 Project supported by Polish National Centre for Research and Development is gratefully acknowledged.

Conflicts of Interest: The authors declare no conflict of interest.

\section{References}

1. Park, E. Positive or negative? Public perceptions of nuclear energy in South Korea: Evidence from Big Data. Nucl. Eng. Technol. 2019, 51, 626-630. [CrossRef]

2. Available online: https://www.nrc.gov/reactors/operating/ops-experience/post-fukushima-safetyenhancements.html (accessed on 27 July 2020).

3. Glinicki, M.A.; Jóźwiak-Niedźwiedzka, D.; Gibas, K.; Dąbrowski, M. Influence of blended cements with calcareous fly ash on chloride ion migration and carbonation resistance of concrete for durable structures. Materials 2016, 9, 18. [CrossRef]

4. Remec, I.; Field, K.G.; Naus, D.J.; Rosseel, T.M.; Busby, J.T. Concrete aging and degradation in NPPs: LWRS program R\&D progress report. Trans. Am. Nucl. Soc. 2014, 109, 403-406.

5. Torrenti, J.-M.; Nahas, G. Durability and safety of concrete structures in the nuclear context. In Concrete under Severe Conditions; Castro-Borges, P., Moreno, E.I., Sakai, K., Gjørv, O.E., Banthia, N., Eds.; Taylor \& Francis Group: London, UK, 2010; pp. 3-18.

6. Kurtis, K.; Xi, Y.; Glinicki, M.A.; Provis, J.; Giannini, E.; Fu, T. Can we design concrete to survive nuclear environments? Concr. Int. 2017, 39, 29-35.

7. Akkurt, I.; Başyiğit, C.; Akkaş, A.; Kılınçarslan, Ş.; Mavi, B.; Günoğl, K. Determination of some heavyweight aggregate half value layer thickness used for radiation shielding. Acta Phys. Pol. A 2012, 121, 138-140. [CrossRef]

8. Glinicki, M.A.; Antolik, A.; Gawlicki, M. Evaluation of compatibility of neutron-shielding boron aggregates with Portland cement in mortar. Constr. Build. Mater. 2018, 164, 731-738. [CrossRef]

9. Ouda, A.S. Development of high-performance heavy density concrete using different aggregates for gamma-ray shielding. Prog. Nucl. Energy 2015, 79, 48-55. [CrossRef]

10. Thomas, C.; Rico, J.; Tamayo, P.; Ballester, F.; Setién, J.; Polanco, J.A. Effect of elevated temperature on the mechanical properties and microstructure of heavy-weight magnetite concrete with steel fibers. Cem. Concr. Compos. 2019, 103, 80-88. [CrossRef]

11. Sakr, K.; El-Hakim, E. Effect of high temperature or fire on heavy weight concrete properties. Cem. Concr. Res. 2005, 35, 590-596. [CrossRef]

12. Yousef, S.; Al Nassar, M.; Naoom, B.; Alhajali, S.; Kharita, M.H. Heat effect on the shielding and strength properties of some local concretes. Prog. Nucl. Energy 2008, 50, 22-26. [CrossRef] 
13. Al-Amoudi, O.S.B.; Al-Kutti, W.A.; Ahmad, S.; Maslehuddin, M. Correlation between compressive strength and certain durability indices of plain and blended cement concretes. Cem. Concr. Compos. 2009, 31, 672-676. [CrossRef]

14. Rashad, A.M. An overview on rheology, mechanical properties and durability of high volume slag used as a cement replacement in paste, mortar and concrete. Constr. Build. Mater. 2018, 187, 89-117. [CrossRef]

15. Giergiczny, Z.; Król, A.; Tałaj, M.; Wandoch, K. Performance of concrete with low $\mathrm{CO}_{2}$ emission. Energies 2020, 13, 4328. [CrossRef]

16. Sanjuán, M.A.; Estévez, E.; Argiz, C.; del Barrio, D. Effect of curing time on granulated blast-furnace slag cement mortars carbonation. Cem. Concr. Compos. 2018, 90, 257-265. [CrossRef]

17. Feng, N.-Q.; Niu, Q.-L.; Li, C.-Z. Improvement of concrete durability by composite cement. Key Eng. Mater. 2009, 405-406, 14-18. [CrossRef]

18. Leemann, A.; Loser, R.; Münch, B. Influence of cement type on ITZ porosity and chloride resistance of self-compacting concrete. Cem. Concr. Compos. 2010, 32, 116-120. [CrossRef]

19. Yang, C.C. On the relationship between pore structure and chloride diffusivity from accelerated chloride migration test in cement-based materials. Cem. Concr. Res. 2006, 36, 1304-1311. [CrossRef]

20. Boumaaza, M.; Turcry, P.; Huet, B.; Ait-Mokhtar, A. Influence of carbonation on the microstructure and the gas diffusivity of hardened cement pastes. Constr. Build. Mater. 2020, 253, 119227. [CrossRef]

21. Tracz, T.; Zdeb, T. Effect of hydration and carbonation progress on the porosity and permeability of cement pastes. Materials 2019, 12, 192. [CrossRef]

22. Linares-Alemparte, P.; Andrade, C.; Baza, D. Porosity and electrical resistivity-based empirical calculation of the oxygen diffusion coefficient in concrete. Constr. Build. Mater. 2019, 198, 710-717. [CrossRef]

23. Gruyaert, E.; Van den Heede, P.; De Belie, N. Carbonation of slag concrete: Effect of the cement replacement level and curing on the carbonation coefficient-Effect of carbonation on the pore structure. Cem. Concr. Compos. 2013, 35, 39-48. [CrossRef]

24. Jóźwiak-Niedźwiedzka, D. Influence of blended cements on the concrete resistance to carbonation. In Proceedings of the 10th International Symposium Brittle Matrix Composites BMC-10, Warsaw, Poland, 15-17 October 2012; Brandt, A.M., Olek, J., Glinicki, M.A., Leung, C.K.Y., Eds.; Woodhead Publishing: Cambridge, UK, 2012; pp. 125-134.

25. Gruyaert, E.; Van den Heede, P.; Maes, M.; De Belie, N. A comparative study of the durability of ordinary Portland cement concrete and concrete containing (high) percentages of blast-furnace slag. In International RILEM Conference on Material Science; Brameshuber, W., Ed.; RILEM Publications: Aachen, Germany, 2010; pp. 241-251.

26. Glinicki, M.A. Długotrwała Funkcjonalność Betonu w Konstrukcjach Osłonowych Elektrowni Jądrowych (Longterm Performance of Concrete in Shielding Structures of Nuclear Power Plants); IPPT PAN: Warszawa, Poland, 2015; p. 64. (In Polish)

27. Kubissa, W.; Glinicki, M.A.; Dabrowski, M. Permeability testing of radiation shielding concrete manufactured at industrial scale. Mater. Struct. 2018, 51, 83. [CrossRef]

28. Zhang, J.; Bian, F.; Zhang, Y.; Fang, Z.; Fu, C.; Guo, J. Effect of pore structures on gas permeability and chloride diffusivity of concrete. Constr. Build. Mater. 2018, 163, 402-413. [CrossRef]

29. Kubissa, W.; Glinicki, M.A. Influence of internal relative humidity and mix design of radiation shielding concrete on air permeability index. Constr. Build. Mater. 2017, 147, 352-361. [CrossRef]

30. Binici, H. Durability of heavyweight concrete containing barite. Int. J. Mater. Res. 2010, 101, 1052-1059. [CrossRef]

31. Zhang, D.; Yang, Q.; Mao, M.; Li, J. Carbonation performance of concrete with fly ash as fine aggregate after stress damage and high temperature exposure. Constr. Build. Mater. 2020, 242, 118125. [CrossRef]

32. Baran, T.; Glinicki, M.A.; Jóźwiak-Niedźwiedzka, D. Properties of special cements for shielding concrete in nuclear power plants. Cem. Wapno Beton 2016, 21, 207-215.

33. PN-EN 12390-3:2019. Testing Hardened Concrete. Compressive Strength of Test Specimens; Polish Committee for Standardization: Warsaw, Poland, 2019; p. 22.

34. NT Build 492:1999. Nordtest Method: Concrete, Mortar and Cement-Based Repair Materials: Chloride Migration Coefficient from Non-Steady-State Migration Experiments; Nordtest: Espoo, Finland, 1999. 
35. PN-EN 13295:2005. Products and Systems for the Protection and Repair of Concrete Structures-Test Methods-Determination of Resistance to Carbonation; Polish Committee for Standardization: Warsaw, Poland, 2005; p. 18.

36. NF P18-459: 2010 Concrete. Testing Hardened Concrete. Testing Porosity and Density; Association Française de Normalisation: La Plaine Saint-Denis, France, 2010.

37. Lura, P.; van Breugel, K.; Maruyama, I. Effect of curing temperature and type of cement on early-age shrinkage of high-performance concrete. Cem. Concr. Res. 2001, 31, 1867-1872. [CrossRef]

38. Hager, I.; Tracz, T.; Choińska, M.; Mróz, K. Effect of cement type on the mechanical behavior and permeability of concrete subjected to high temperatures. Materials 2019, 12, 3021. [CrossRef]

39. Horszczaruk, E.; Sikora, P.; Zaporowski, P. Mechanical properties of shielding concrete with magnetite aggregate subjected to high temperature. Procedia Eng. 2015, 108, 39-46. [CrossRef]

40. Petrounias, P.; Giannakopoulou, P.P.; Rogkala, A.; Stamatis, P.M.; Lampropoulou, P.; Tsikouras, B.; Hatzipanagiotou, K. The effect of petrographic characteristics and physico-mechanical properties of aggregates on the quality of concrete. Minerals 2018, 8, 577. [CrossRef]

41. Almenas, K.; Kaliatka, A.; Uspuras, E. Ignalina RBMK-1500, A Source Book; Lithuanian Energy Institute: Kaunas, Lithuania, 1998; p. 198.

42. Giergiczny, Z.; Glinicki, M.A.; Sokołowski, M.; Zieliński, M. Air void system and frost salt scaling of concrete containing slag blended cement. Constr. Build. Mater. 2009, 23, 2451-2456. [CrossRef]

43. Jaskulski, R.; Glinicki, M.A.; Kubissa, W.; Dabrowski, M. Application of a non-stationary method in determination of the thermal properties of radiation shielding concrete with heavy and hydrous aggregate. Int. J. Heat Mass Trans. 2019, 130, 882-892. [CrossRef]

44. Kropp, J. RILEM Technical Recommendation: Tests for gas permeability of concrete, TC 116-PCD: Permeability of concrete as criterion of its durability. Mater. Struct. 1999, 32, 174-179.

(C) 2020 by the authors. Licensee MDPI, Basel, Switzerland. This article is an open access article distributed under the terms and conditions of the Creative Commons Attribution (CC BY) license (http://creativecommons.org/licenses/by/4.0/). 